\title{
Special Educators' Teaching Self-Efficacy Determination: A Quantitative Approach
}

\author{
Alexandros-Stamatios Antoniou', Ioannis Geralexis², Garyfalia Charitaki1 \\ ${ }^{1}$ Faculty of Primary Education, National and Kapodistrian University of Athens, Athens, Greece \\ ${ }^{2}$ Cass School of Education, AKMI Metropolitan College in Collaboration with University of East London, Athens, Greece \\ Email: asantoni@hol.gr,giannisgeralexis.e@gmail.com,charitaki@hotmail.com
}

How to cite this paper: Antoniou, A.-S., Geralexis, I., \& Charitaki, G. (2017). Special Educators' Teaching Self-Efficacy Determination: A Quantitative Approach. Psychology, 8, 1642-1656.

https://doi.org/10.4236/psych.2017.811108

Received: July 15, 2017

Accepted: August 28, 2017

Published: August 31, 2017

Copyright (c) 2017 by authors and Scientific Research Publishing Inc. This work is licensed under the Creative Commons Attribution International License (CC BY 4.0).

http://creativecommons.org/licenses/by/4.0/

(c) (i) Open Access

\begin{abstract}
Through this quantitative educational approach, there is an attempt to depict and evaluate the Teaching Self-Efficacy of special educators. The research sample consisted of 200 special educators employed in public special education structures in Greece. The Teachers' Sense of Efficacy Scale [TSES] was utilized as a research tool. The data collection duration was 2 months (October 2016-November 2016). Results depict high scores in special educators' Self-Efficacy. No differentiation to Self-Efficacy in relation to gender, experience and age, was identified, which coincides with the findings of recent studies. The results of the study are discussed in terms of educational placement.
\end{abstract}

\section{Keywords}

Teacher's Self-Efficacy, Instruction Strategies, Class Management, Student Involvement, Burn Out

\section{Introduction}

There are various theoretical models which aim to interpret and depict Teaching Efficacy (Scheerens \& Bosker, 1997). According to Kyriakidis \& Antoniou (2010), Teaching Efficacy is considered to be not only non-static, but also dependent on factors such as school atmosphere, family background, student behavior and mainly the role of the teacher in the classroom. Thus, it can be assumed that Teachers' Self-Efficacy is inseparably linked with a plethora of educational variables, such as the school structure, the students and of course the teachers themselves (Evers et al., 2002). Emmer \& Hickman (1991) state that the examination of Teachers' Self-Efficacy should include the classroom, which is a place of strategic importance where self-efficacy is manifested and should of 
course be examined.

\section{Theoretical Background}

According to literature related with the measurement of special educators self-efficacy, an holistic non-targeted approach can be observed, with the use of general measurement instruments, which lack a specific framework and often obscure the concept of self-efficacy, isolating it from the situations, the context and the work related to it and presenting it as a generalized attribute of someone's personality (Pajares, 1997). Moreover, the examination of a special educator's self-efficacy via a measurement instrument should include the classroom, which is of strategic importance and where self-efficacy is manifested and should of course be studied (Emmer \& Hickman, 1991).

Among various theories developed regarding the exploration of beliefs concerning their evolution on a personal and professional level, the theory of self-efficacy constitutes a theory which has been studied in depth. Self-efficacy as a concept is found in literature as "perceived self-efficacy", which is determined by the person's perceptions and beliefs about his/her self-efficacy. Thus, it can be concluded that self-efficacy entails the element of the individual-internal perception of the person, through an internal assessment (Tschannen-Moran \& Hoy, 2007; Tschannen-Moran et al., 1998).

The perception level of self-efficacy, however, is also an indicator of the outcome of future goals, a regulatory factor. Specifically, individuals with an acute perception of self-efficacy, in case of failing to achieve a goal, will prevent emotions of failure and abandonment of effort and will persistently be led to the fulfillment of the goal and maybe a new even more demanding goal setting. Low self-efficacy leads to a gradual undermining of a person's self-confidence, an easy abandonment of effort, a cultivation of insecurity and the upcoming degradation of goals. Therefore, the perception of self-efficacy can predict the future actions of the person-educator and the course-accomplishment or not of goals which have been initially set (Bandura \& Locke, 2003).

Although literature is poor regarding the relation between emotional intelligence and the perception of self-efficacy, the current research date reveals that emotional intelligence is a key factor which contributes to the development of the perception of educators' self-efficacy (Chan, 2004).

Many studies about the effect of emotional intelligence on the perception of educators' self-efficacy (Chan, 2004; Salami, 2007; Rastegar \& Memarpour, 2009) showcased the positive correlation between emotional intelligence and educators' self-efficacy in a sample of secondary education teachers. Since 1997, in Bandura's sociocognitive theory the control of emotions, self-regulation and empathy, features which constitute the ingredients of emotional intelligence, have been of vital importance with regard to the perception of self-efficacy (Bandura, 1997).

Special educators self-efficacy determination is tightly linked to a great number 
of variables which concern the school organization or any other structure in which an educator becomes active, the variety of students and of course himself (Evers et al., 2002). In conditions of smooth functioning of the external variables, the educator feels able to respond to the demands, sets realistic goals and maintains a positive perception of his self-efficacy. Failing to fulfill the goals unsettles the educator himself, his self-efficacy and his ambitions about the future for fear of an upcoming repetitive failure (Tschannen-Moran \& Hoy, 2007).

The perception of educators' self-efficacy affects teaching practices, his mobilization in the classroom and the management of students (see Table 1). According to research findings, high rates of an educator's self-efficacy are usually combined with the self-efficacy and the learning accomplishments of his students themselves (Henson et al., 2001). Educators with high self-efficacy are characterized by high levels of organization, dedication, thorough planning of instruction, strong mobilization and feedback to their students as well as successful classroom management in unstable learning environments (Fives, 2003).

Educators with high rates of self-efficacy do not adopt hegemonic teaching methods. On the contrary, they implement innovative educational programs, they are not critical towards their students and they spend more energy supporting and activating weak students. Self-efficacy renders educators excellent "managers" of the classroom with high adaptability to unexpected situations and more successful management of the learning population (see Table 2) (Tschannen-Moran \& Hoy, 2007).

The benefits of students due to the presence of an educator with high self-efficacy are evident. Specifically, research data favors a relation of positive pertinence between self-efficacy and the achievement of student autonomy. This achievement is possible due to the enrichment of the learning environment, the

Table 1. Instruction strategies efficacy level.

\begin{tabular}{ccc}
\hline & $\begin{array}{c}\text { Mean } \\
(\mathrm{m})\end{array}$ & $\begin{array}{c}\text { Standard } \\
\text { Deviation (sd) }\end{array}$ \\
\hline $\begin{array}{c}\text { How well can you respond to your students' difficult questions? } \\
\text { How much can you assess the students' comprehension }\end{array}$ & 4.43 & 0.727 \\
How much can you construct good questions for your students? & 4.43 & 0.760 \\
How much can you do to adapt your lessons to an appropriate & 4.10 & 0.630 \\
level for each student separately? & 0.613 \\
How much can you use a range of assessment strategies? & 4.28 & 0.811 \\
How much can you provide an alternative explanation & 4.26 & 0.587 \\
or example when students are confused? & & 0.739 \\
How well can you apply alternative strategies in your class? & 4.42 & 0.634 \\
How well can you provide alternative challenges \\
for the very apt students?
\end{tabular}


Table 2. Class management efficacy level.

\begin{tabular}{|c|c|c|}
\hline & $\begin{array}{c}\text { Mean } \\
(\mathrm{m})\end{array}$ & $\begin{array}{c}\text { Standard } \\
\text { Deviation (Sd) }\end{array}$ \\
\hline $\begin{array}{l}\text { How much can you do to control the disturbed } \\
\text { behavior in the classroom? }\end{array}$ & 4.15 & 0.666 \\
\hline $\begin{array}{c}\text { To what degree can you make your expectations of } \\
\text { student conduct clear? }\end{array}$ & 4.32 & 0.755 \\
\hline $\begin{array}{l}\text { How well can you impose daily procedures so that } \\
\text { activities can run smoothly? }\end{array}$ & 4.14 & 0.723 \\
\hline $\begin{array}{l}\text { How much can you do to convince students } \\
\text { to follow the class rules? }\end{array}$ & 4.20 & 0.591 \\
\hline $\begin{array}{l}\text { How much can you do to appease a student } \\
\text { who is naughty or noisy? }\end{array}$ & 4.17 & 0.681 \\
\hline $\begin{array}{l}\text { How well can you impose a system of class } \\
\text { management for every student group? }\end{array}$ & 4.42 & 0.697 \\
\hline $\begin{array}{c}\text { To what degree can you prevent some problematic } \\
\text { students from ruining a whole lesson? }\end{array}$ & 4.20 & 0.761 \\
\hline How well can you deal with aggressive students? & 4.05 & 0.819 \\
\hline Class management efficacy & 4.21 & 0.492 \\
\hline
\end{tabular}

encouragement of autonomous action and the restriction of control, which are provided within the framework of instruction by educators with powerful self-efficacy (Caprara et al., 2006).

On the other hand, educators with low rates of self-efficacy are driven to the undermining of their expectations concerning their students and the educational work produced. This fact leads to professional stagnation, the abandonment of teaching methods and strategies and the voluntary unconsidered surrender (Tschannen-Moran \& Hoy, 2007). The level of preparation and proper quality training of the educator are an index of his self-efficacy. Usually, high rates of self-efficacy are combined with upcoming future professional satisfaction; stay on the job, devotion to teaching and professional recognition. Additionally, cooperating with colleagues, cooperativeness and an interdisciplinary approach are qualities of educators with high levels of self-efficacy showing a positive pertinence and interactive relation which is derived from self-efficacy as a measurable variable (Sartawi \& Alghazo, 2006).

The study of special educators' self-efficacy as a whole is extremely restricted since most studies focus on a research sample belonging to general education (Coladarci \& Breton, 1997). In one of their studies on educators of induction courses aiming at researching self-efficacy Coladarci \& Breton (1997) concluded the following. The educators who portrayed high levels of self-efficacy were characterized by strict organization and intense excitement and class feedback. Moreover, what was observed was willingness to experiment and use new methods and approaches beyond typical instruction with obvious abilities to better manage the class and respond to unexpected situations especially stressful for 
the educator (Coladarci \& Breton, 1997).

Additionally, it should be mentioned that there is a lack of recent data concerning Teachers' Self-Efficacy in relation to instruction strategies, class management and student involvement. Previous relevant studies do exist, however, in the last five years, when there is a tremendous increase of teachers' training; there is no corresponding research data in Greece. The aim of the study was to investigate Special Educators' Teaching Self-Efficacy in relation to instruction strategies, class management and student involvement.

\section{Method}

\subsection{Research Design}

For the aforementioned purpose, quantitative empirical research was chosen. More specifically, the study represents a research overview of special educators' perceptions about their Teaching Self-Efficacy.

\subsection{Sample-Participants}

The research sample was determined through convenience sampling. The sample consisted of 200 Special Educators, who comprise a representative sample of special educators in Greece. Concerning their demographic characteristics, 53.5\% of the participants were female and $45.5 \%$ were male. The majority of the participants were relatively young, with a mean age of 25.1 years $(\mathrm{sd}=4.7)$.

\subsection{Research Tools}

For the purpose of data collection, the study utilised the translated and adapted version of the Teachers' Sense of Efficacy Scale [TSES] (Tschannen-Moran \& Hoy, 2001; Poulou, 2015). This scale consists of 24 sentences, which form three sub-scales of the educator's Self-Efficacy. The subscales include instruction strategies, class management and student involvement. The participants are invited to state the degree to which they consider every sentence characterizes them using a Likert-type scale of five levels $(1=$ does not apply to me at all, $5=$ fully applies to me). The credibility of conceptual construction was studied through con-firm $=$ min analysis of factors. More specifically, the credibility indicators of repeat measurements for the scale sentences fluctuated from 0.41 to 0.89 and the credibility of internal consistency for the sub-scales fluctuated from 0.78 to 0.82 (Stalikas, Trivila, \& Roussi, 2012). In addition, the participants provided in-formation with regard to certain demographic data such as sex, year of studies, department of studies, age.

\subsection{Validity and Reliability of Teachers' Sense of Efficacy Scale [TSES]}

Given the grouping of questions of the Special Educators' Teaching Self-Efficacy scales into sub-scales, both the research tool as a whole and the sub-scales were analysed for their internal relevance and reliability, and Cronbach's alpha index 
was calculated. Cronbach's Alpha was satisfactory for the sub-scales of student involvement efficacy, instruction strategies efficacy and class management efficacy (see Table 3 ). The Alpha reliability index is considered exceptionally high for the whole questionnaire equaling 0.917 .

\subsection{Research Questions}

Through this research we attempted to answer the following research questions:

1) What is the level of the special educators' Self-Perception in relation to their Instruction Strategies?

2) What is the level of the special educators' Self-Perception in relation to Class Management?

3) What is the level of the Educators' Self-Perception in relation to Student Involvement?

4) Do demographic factors (gender, age, year of studying, department) of special educators affect their perceptions regarding their Teaching Self-Efficacy?

5) What are the special characteristics of the special educators' Teaching Self-Efficacy as stated by them?

6) Is there a correlation of the special educators' Self-Perception among the sub-scales under study (instruction strategies-class management-student involvement)?

\section{Data Analysis}

\section{Statistical Tools}

In order to draw conclusions and check the predefined research hypotheses, simple methods of descriptive statistics as well as techniques of inductive statistics through checking hypotheses were used. Specifically, the percentages of answers provided by the respondents are shown in the form of bar graphs and pie charts. For the analysis of the quantitative data were used the statistical criterions of Spearman, Mann-Whitney $\mathrm{U}$ and Kruskal-Wallis $\mathrm{H}$. The significance level was determined at $\mathrm{a}=5 \%$.

\section{Results}

\subsection{Results of Descriptive Statistics-Demographic Data}

Concerning the demographic data of the participating educators, $53.5 \%$ of the

Table 3. Cronbach's alpha of the whole scale and the sub-scales of educators' teaching efficacy.

\begin{tabular}{cc}
\hline & Cronbach's alpha \\
\hline Student Involvement Efficacy & 0.796 \\
Instruction Strategies Efficacy & 0.873 \\
Class Management Efficacy & 0.842 \\
Special Educators' Teaching Self-Efficacy scales & 0.917 \\
\hline
\end{tabular}


sample population was female and $46.5 \%$ was male. The average age of the educators was $25.1 \pm 4.7$ years (see Table 4 ).

Analysis of the demographic data of the sample revealed a large percentage of male participants, comprising almost half of the sample population (46.5\%). This adds an interesting perspective to the present study, demolishing the common phenomenon of female educators being the main subject of research, thus preserving a deeply founded stereotype that being an educator is a female profession (Ross, 1994; Kiousi, Florakos, \& Papkitsos, 2017). A large percentage, comprising the $43.5 \%$ of the sample, consisted of post-graduate students in the field of special education, who, however, are active educators with regard to teaching. This fact accounts for the low average age which was formed at 25 years old (see Table 4). The following analysis and its conclusions are expected to enlighten us concerning the younger generation of special educators, their self-efficacy and the level of their studies.

\subsection{Student Involvement Efficacy Level}

With regard to the analysis of the statements which comprise the Educators' teaching Self-efficacy Scale and focusing on the sub-scale of the educators' efficacy in relation to student involvement, it can be observed that the average rate of the specific sub-scale is high equaling 4.14 ( $\mathrm{sd}=0.428)$ indicating that the educators' efficacy in terms of student involvement is considered highly satisfactory (see Table 5).

Table 4. Mean and S.D. of age of respondents.

\begin{tabular}{ccc}
\hline & \multicolumn{3}{c}{ Descriptive Statistics } \\
\cline { 2 - 3 } & $\begin{array}{c}\text { Mean } \\
(\mathrm{m})\end{array}$ & $\begin{array}{c}\text { Standard } \\
\text { Age }\end{array}$ \\
\hline
\end{tabular}

Table 5. Student involvement efficacy level.

\begin{tabular}{|c|c|c|}
\hline & $\begin{array}{c}\text { Mean } \\
(\mathrm{m})\end{array}$ & $\begin{array}{c}\text { Standard } \\
\text { Deviation (sd) }\end{array}$ \\
\hline How much can you do to make yourself understood to tougher students? & 4.17 & 0.663 \\
\hline How much can you do to help your students develop critical thinking? & 3.79 & 0.727 \\
\hline $\begin{array}{l}\text { How much can you do to motivate students who } \\
\text { portray a decreased interest in schoolwork? }\end{array}$ & 4.08 & 0.743 \\
\hline $\begin{array}{l}\text { How much can you do to convince your students } \\
\text { that they can do well at school? }\end{array}$ & 4.14 & 0.626 \\
\hline How much can you do to help your students appreciate learning? & 4.15 & 0.688 \\
\hline How much can you do to reinforce your students' creativity? & 4.24 & 0.665 \\
\hline How much can you do to boost the comprehension of a student who fails? & 4.16 & 0.602 \\
\hline How much can you assist families to help their children do well at school? & 4.42 & 0.605 \\
\hline Student involvement efficacy & 4.14 & 0.428 \\
\hline
\end{tabular}


More specifically, the educators indicate an strong ability to provide families with assistance so that the families can help their children to do well at school $(\mathrm{m}=4.42$, sd $=0.605)$, and educators can take the right steps to reinforce the students' creativity $(\mathrm{m}=4.24, \mathrm{sd}=0.665)$. The educators' efficacy concerning the level of their actions to make themselves understood by students $(\mathrm{m}=4.17$, $\mathrm{sd}=0.663)$, to improve the comprehension of students who fail $(\mathrm{m}=4.16, \mathrm{sd}=$ $0.602)$, to help students appreciate learning $(\mathrm{m}=4.15$, $\mathrm{sd}=0.668)$ and to convince them that they can do well at school $(\mathrm{m}=4.14$, sd $=0.626)$ is slightly lower, although still relatively high. The average rate of the degree to which the responding educators can activate the students who portray reduced interest in schoolwork equals 4.08 ( $(\mathrm{d}=0.743$ ), whereas the efficacy of educators with regard to offering help to students in order to develop their critical thinking is lower.

\subsection{Instruction Strategies Self-Efficacy Level}

The efficacy of educators in relation to the applied instruction strategies is also considerably high as the grading of the corresponding sub-scale equals 4.38 ( $\mathrm{sd}=$ 0.503). The educators' efficacy is high with regard to providing suitable challenges for the very apt students $(\mathrm{m}=4.53)$, constructing good questions for students $(\mathrm{m}=4.58$; $\mathrm{sd}=0.630)$, their responsiveness to students' difficult questions $(\mathrm{m}=4.43 ; \mathrm{sd}=0.727)$, their ability to assess students' comprehension of the teaching material $(\mathrm{m}=4.43$; $\mathrm{sd}=0.739)$ and the application of alternative educational strategies $(\mathrm{m}=4.42$; $\mathrm{sd}=0.739)$. The efficacy of educators concerning their ability to use assessment strategies $(\mathrm{m}=4.28$; $\mathrm{sd}=0.811)$, to provide students with alternative explanations $(\mathrm{m}=4.26$; $\mathrm{sd}=0.587)$ and to adapt the lessons to the appropriate level for each student separately $(\mathrm{m}=4.10$; $\mathrm{sd}=0.613)$ is slightly lower (see Table 1).

\subsection{Class Management Self-Efficacy Level}

Participants also demonstrated high self-efficacy in relation to class management (see Table 2). The average score for this particular sub-scale equals $4.21(\mathrm{sd}=$ 0.492 ) as educators seem to possess a remarkably good ability to impose a system of class management for every student group $(\mathrm{m}=4.42$; $\mathrm{sd}=0.697)$ and to clearly determine their expectations in relation to student behavior $(\mathrm{m}=4.32$; sd $=0.755)$. Efficacy is also high in connection to educators' ability to convince students to follow the class rules, and to prevent problematic students from disrupting the lesson with an average score of $4.20(\mathrm{sd}=0.591$ and 0.761$)$ respectively. Average scores of respondents concerning their ability to appease the students who misbehave equals 4.17 ( $\mathrm{sd}=0.681$ ), whilst their ability to control disturbed behavior in the classroom equals $4.15(\mathrm{sd}=0.666)$ and imposing daily procedures so that activities can run smoothly equals $4.14(\mathrm{sd}=0.723)$. The ability of educators to deal with aggressive students is slightly lower with an average grading of the corresponding question equal to $4.05(\mathrm{sd}=0.819)$ (see Table 2). 


\subsection{Results of Conductive Statistics}

Examining whether the premises of the research follow the regular distribution is essential in order to begin the procedure of drawing conclusions and testing our hypotheses. From the data normality checks applying the Kolmogorov-Smirnov methods for the three sub-scales of the Educators' Teaching Self-efficacy scale, it appears that they do not follow the regular distribution as the corresponding checks have a $\mathrm{p}$-value which is lower than the $\mathrm{a}=0.05$ significance level (see Table 6). Consequently, non-parametric statistical tools will be used to conduct hypotheses checks.

\subsection{Correlations of the Sub-Scales}

The correlation of the sub-scales within the research tool through the use of Spearman's non parametric co-efficient of linear correlation rho is positive and statistically important (see Table 7). Specifically, the correlation co-efficient of student involvement efficacy and strategy instruction efficacy equals 0.700 ( $p<$ 0.001 ) meaning that the higher the educators' ability in terms of student involvement, the more increased the effective application of instruction strategies and vice versa. Likewise, the correlation co-efficient between the sub-scale of student involvement efficacy and the sub-scale of class management efficacy equals $0.431(p<0.001)$ thus, the ability of educators to maximally involve students results in higher expectations concerning class management efficacy. Finally,

Table 6. Regularity variables checks.

\begin{tabular}{ccccccc}
\hline & \multicolumn{3}{c}{ Kolmogorov-Smirnov } & \multicolumn{3}{c}{ Shapiro-Wilk } \\
\cline { 2 - 6 } & Statistic & Df & P & Statistic & Df & $\mathrm{p}$ \\
\hline $\begin{array}{c}\text { Student involvement } \\
\text { efficacy }\end{array}$ & 0.132 & 200 & 0.000 & 0.959 & 200 & 0.000 \\
$\begin{array}{c}\text { Instruction strategies } \\
\text { efficacy }\end{array}$ & 0.198 & 200 & 0.000 & 0.892 & 200 & 0.000 \\
$\begin{array}{c}\text { Class management } \\
\text { efficacy }\end{array}$ & 0.105 & 200 & 0.000 & 0.956 & 200 & 0.000 \\
\hline
\end{tabular}

Table 7. Spearman correlation of the sub-scales of educators' teaching self-efficacy.

\begin{tabular}{|c|c|c|c|c|}
\hline & & $\begin{array}{c}\text { Student } \\
\text { involvement } \\
\text { efficacy }\end{array}$ & $\begin{array}{c}\text { Instruction } \\
\text { strategies efficacy }\end{array}$ & $\begin{array}{c}\text { Class } \\
\text { management } \\
\text { efficacy }\end{array}$ \\
\hline Student & Rho & 1 & - & - \\
\hline $\begin{array}{c}\text { involvement } \\
\text { efficacy }\end{array}$ & $\mathrm{P}$ & - & - & - \\
\hline Instruction & Rho & 0.700 & 1 & - \\
\hline strategies efficacy & $\mathrm{P}$ & 0.000 & - & - \\
\hline Class management & Rho & 0.431 & 0.605 & 1 \\
\hline efficacy & $\mathrm{P}$ & 0.000 & 0.000 & - \\
\hline
\end{tabular}


the rho co-efficient is positive $(0.605, \mathrm{p}$-value $<0.001)$ concerning the application of instruction strategies efficacy and the class management efficiency revealing the connection between the application of theoretical models of instruction and the satisfactory manner of class management.

\subsection{The Effect of Gender}

As regards the effect of gender on the average gradings of the subscales through the use of the Mann-Whitney U test, it can be observed that there is no statistically significant difference between the average gradings of the student involvement efficacy scale $(p=0.699)$, the strategies instruction efficacy scale ( $p=$ $0.829)$ and the class management efficacy scale $(p=0.137)$ (see Table 8).

The fact that there is no statistically significant differentiation of gender as a factor which affects the self-efficacy of special educators is an important finding which disproves the general tendency of relevant studies to establish a supremacy of women over men as regards self-efficacy (Ross, 1994; Kiousi, Florakos, \& Papakitsos, 2017) and it is aligned with the findings of recent studies according to which there is no differentiation of self-efficacy of educators on the basis of gender (Tschannen-Moran \& Hoy, 2007).

\subsection{The Effect of Age}

The Spearman correlation co-efficient of the three sub-scales and the educators' age is not statistically significant ( $p>0.05$ in all cases) (see Table 9). Thus, age is not a determining factor of educators' self-efficacy.

\subsection{The Effect of Experience}

Finally, utilising the Mann-Whitney U statistics, it was revealed that the faculty within which the re-spondents study does not influence the level of educators' teaching self-efficacy ( $p>0.05$ in all cases). The results are derived from the respondents' year of studies in correlation of the level of teaching self-efficacy through the Kruskal-Wallis $\mathrm{H}$ criterion.

Table 8. Mann-Whitney check of the effect of gender on the average gradings of the sub-scales of educators' teaching self-efficacy.

\begin{tabular}{cccccc}
\hline & \multicolumn{5}{c}{ Gender } \\
\cline { 2 - 4 } & \multicolumn{3}{c}{ Male } & Female & $p$ \\
\cline { 2 - 4 } & $\begin{array}{c}\text { Mean } \\
(\mathrm{m})\end{array}$ & $\begin{array}{c}\text { Standard } \\
\text { Deviation (Sd) }\end{array}$ & $\begin{array}{c}\text { Mean } \\
(\mathrm{m})\end{array}$ & $\begin{array}{c}\text { Standard } \\
\text { Deviation (Sd) }\end{array}$ & 0.699 \\
$\begin{array}{c}\text { Student } \\
\text { involvement efficacy }\end{array}$ & 4.15 & 0.45 & 4.13 & 0.41 & 0.829 \\
$\begin{array}{c}\text { Strategies instruction } \\
\text { efficacy }\end{array}$ & 4.39 & 0.49 & 4.37 & 0.51 & 0.137 \\
$\begin{array}{c}\text { Class management } \\
\text { efficacy }\end{array}$ & 4.26 & 0.50 & 4.16 & 0.48 & \\
\hline
\end{tabular}


Table 9. Spearman correlation of the subscales of educators' teaching self-efficacy and age.

\begin{tabular}{lcl}
\hline & & Age \\
\hline Student involvement efficacy & Rho & 0.053 \\
& $\mathrm{P}$ & 0.457 \\
Strategies instruction efficacy & Rho & 0.075 \\
& $\mathrm{P}$ & 0.292 \\
Class management efficacy & Rho & 0.090 \\
& $\mathrm{P}$ & 0.209 \\
\hline
\end{tabular}

\section{Discussion}

With regard to the research questions which were initially posed, the findings indicate the following: High levels of self-efficacy were identified for the representative sample of special educators, in all sub-scales of the measure used for this research, with no statistically significant differentiations with regard to gender, experience and age, thus coinciding with the findings of other recent studies (Tschannen-Moran \& Hoy, 2007).

Based on the analysis of data in the sub-scale measuring self-efficacy in relation to the degree of student involvement, it is evident that the educators portray high levels of self-efficacy. This fact could be associated to their engagement in post-graduate studies as well as their age and the ongoing training that they receive. In recent years, a gradual tendency for further training has been observed, mainly through seminars or the continuation of studies at a higher level. As such, educators indicate high self-efficacy percentages within the framework of student involvement, being able to enrich the creativity of the lesson through the use of new technologies or innovative instruction strategies, as shown below (Goldhaber, Krieg, \& Theobald, 2014; Xochelis, 2002).

In addition, the results revealed that self-efficacy concerning the applied instruction strategies was also high. The success of educators in applying alternative instruction strategies by using a range of assessment strategies and by constructing correct and representative questions for students does not only indicate the effect of training and the high level of their studies, but it also confirms the effect of the low average age, which automatically sets them away from situations of intense stress and professional exhaustion, which do not plague young educators. This fact is confirmed by relevant studies, which show that there is a minimal correlation between prior experience and efficacy concerning classroom instruction strategies (Zee \& Koomen, 2016; Dixon, Yssel, McConnell, \& Hardin, 2014; Prieto \& Altmaier, 1994).

As in similar studies, the present study confirms that educators with high self-efficacy proceed to the creation of an enriched learning environment, which supports students by using innovative teaching methods and experimentation, and they are full of enthusiasm (Sartawi \& Alghazo, 2006).

The analysis of data in relation to the educators' class management efficacy 
and the complex and multifactorial relations which are formed within it reveals high scores for self-efficacy. The classroom is a subarea of strategic importance where the educator's self-efficacy is revealed, thus making its measurement extremely valuable, and demonstrating the overall management of the teaching act within the class-room (Ozdemir, 2007). The high levels of self-efficacy concerning class management also reveal the educators' belief that they can respond to the pressure of work. Within a framework of self-regulation the self-efficient educator poses realistic and specific objectives, which lead to positive teaching practices, student motivation, student involvement, visible learning results and increased levels of Self-Efficacy for the students themselves (Caprara et al., 2006; Henson et al., 2001).

According to Fives (2003) the high levels of special educators' Self-Efficacy represent an effort to boost and cultivate students' self-management, excluding regal methods of teaching. Educators who score high in terms of self-efficacy also manage to deal with the fluidity and the uncertainty of the classroom, thus developing ways of successful class management (Fives, 2003). The above findings are fully aligned with the conclusions of the present study as the recording of the educators' high self-efficacy is accompanied by the ability of class management, the confrontation of fluid situations and the ability to manage various groups and aggressive students.

Both age and sex as factors affecting self-efficacy do not seem to significantly affect the levels of self-efficacy. A study by Tschannen-Moran \& Hoy (2007), involving a sample of 255 teachers in the USA showed a differentiation of young educators who portrayed less self-efficacy than the more experienced educators who had 4 or more years of service.

However, in the present study the special educators of the sample had indicated an average work experience of 3 years and the majority of them were young, thus comprising a homogeneous sample. The noteworthy performance in the measurement of self-efficacy per sub-scale enables not only to depict the phenomenon in consideration of Greek educational system, but also offers feedback for new studies aiming at researching it. The high level of the educators' studies, the level of training of the Greek special educators and the fact that the sample consists of special educators who possess post-graduate degrees or are about to acquire them, may possibly explain the above finding.

\section{Conclusion}

Teachers' self-assurance in their ability to accomplish in a way which leads to student learning is a characteristic of major importance which is highly correlated with educational process (Poulou, 2007). Special Education is a demanding field of training where strong beliefs are of principal importance. Their perceptions about instructional strategies, classroom management and students' engagement in relation to Teaching Self Efficacy show that Special Educators can cope with the educational difficulties due to their level of training and their 
experience in special education classrooms.

\section{Study Limitations-Future Propositions}

Given the insufficient focus and research in the field of special education in Greece, the conclusions drawn from this study are considered important and are expected to enrich the scientific research and trigger new studies in the field of special education. The research data can be considered for a future enrichment through further pilot research with the exploitation of information and through quality research methods. Valuable material and essential feedback of the research tool can be derived from interviews with special educators, thus achieving a thorough collection of qualitative data.

An additional future perspective of research may include the assessment of the self-efficacy of undergraduate special educators compared to holders of postgraduate degrees. It also worth research such a distinction since it is a subject of political-legislative speculation and differentiation.

\section{References}

Bandura, A. (1997). Self-Efficacy: The Exercise of Control. Macmillan.

Bandura, A., \& Locke, E. A. (2003). Negative Self-Efficacy and Goal Effects Revisited. Journal of Applied Psychology, 88, 87-99. https://doi.org/10.1037/0021-9010.88.1.87

Caprara, G. V., Barbaranelli, C., Steca, P., \& Malone, P. S. (2006). Teachers' Self-Efficacy Beliefs as Determinants of Job Satisfaction and Students' Academic Achievement: A Study at the School Level. Journal of School Psychology, 44, 473-490. https://doi.org/10.1016/j.jsp.2006.09.001

Chan, D. W. (2004). Perceived Emotional Intelligence and Self-Efficacy among Chinese Secondary School Teachers in Hong Kong. Personality and Individual Differences, 36, 1781-1795. https://doi.org/10.1016/j.paid.2003.07.007

Coladarci, T., \& Breton W. A. (1997). Teacher Efficacy, Supervision, and the Special Education Resource-Room Teacher. The Journal of Educational Research, 90, 230-239. https://doi.org/10.1080/00220671.1997.10544577

Dixon, F. A., Yssel, N., McConnell, J. M., \& Hardin, T. (2014). Differentiated Instruction, Professional Development, and Teacher Efficacy. Journal for the Education of the Gifted, 37, 111-127. https://doi.org/10.1177/0162353214529042

Emmer, E. T., \& Hickman, J. (1991). Teacher Efficacy in Classroom Management and Discipline. Educational and Psychological Measurement, 51, 755-765. https://doi.org/10.1177/0013164491513027

Evers, W. J., Brouwers, A., \& Tomic, W. (2002). Burnout and Self-Efficacy: A Study on Teachers' Beliefs When Implementing an Innovative Educational System in the Netherlands. British Journal of Educational Psychology, 72, 227-243. https://doi.org/10.1348/000709902158865

Fives, H. (2003). What Is Teacher Efficacy and How Does It Relate to Teachers' Knowledge? A Theoretical Review. In: American Educational Research Association Annual Conference (pp. 1-59). Chicago: The University of Maryland. https://msuweb.montclair.edu/ fivesh/Research_files/Fives_AERA_2003.pdf

Goldhaber, D., Krieg, J., \& Theobald, R. (2014). Knocking on the Door to the Teaching Profession? Modeling the Entry of Prospective Teachers into the Workforce. Economics of Education Review, 43, 106-124. https://doi.org/10.1016/j.econedurev.2014.10.003 
Henson, R. K., Kogan, L. R., \& Vacha-Haase, T. (2001). A Reliability Generalization Study of the Teacher Efficacy Scale and Related Instruments. Educational and Psychological Measurement, 61, 404-420. https://doi.org/10.1177/00131640121971284

Kiousi, E., Florakos, G., \& Papakitsos, E. X. (2017). Gender Stereotypes and Study Choice in Depending on Gender in Secondary Education. Research in Education, 6, 95-111.

Kyriakidis, L., \& Antoniou, P. (2010). Theoretical Models of Educational Efficiency: Measuring School Effectiveness. In P. Pasiardis (Ed.), Change Management, School Efficiency and Strategic Planning (p. 1). Nicosia: Open University of Cyprus.

Ozdemir, Y. (2007). The Role of Classroom Management Efficacy in Predicting Teacher Burnout. International Journal of Social Sciences, 2, 257-263.

Pajares, F. (1997). Current Directions in Self-Efficacy Research. Advances in Motivation and Achievement, 10, 1-49.

Poulou, M. (2007). Personal Teaching Efficacy and Its Sources: Student Teachers' Perceptions. Educational Psychology, 27, 191-218. https://doi.org/10.1080/01443410601066693

Poulou, M. (2015). Teacher Social and Emotional Skills, Teacher Relations and Student Behavior: Teacher Perceptions. Hellenic Journal of Psychology, 12, 129-155.

Prieto, L. R., \& Altmaier, E. M. (1994). The Relationship of Prior Training and Previous Teaching Experience to Self-Efficacy among Graduate Teaching Assistants. Research in Higher Education, 35, 481-497. https://doi.org/10.1007/BF02496384

Rastegar, M., \& Memarpour, S. (2009). The Relationship between Emotional Intelligence and Self-Efficacy among Iranian EFL Teachers. System, 37, 700-709. https://doi.org/10.1016/j.system.2009.09.013

Ross, J. A. (1994). Beliefs That Make a Difference: The Origins and Impacts of Teacher Efficacy. Calgary, Alberta: The Annual Meeting of the Canadian Association for Curriculum Studies.

Salami, S. O. (2007). Relationships of Emotional Intelligence and Self-Efficacy to Work Attitudes among Secondary School Teachers in Southern Nigeria. Essays in Education, 20, 43-56.

Sartawi, A., \& Alghazo, E. M. (2006). Special Education Teachers' Perceptions of Factors Influencing Their Instructional Practices. International Journal of Rehabilitation Research, 29, 161-165. https://doi.org/10.1097/01.mrr.0000210049.86796.1a

Scheerens, J., \& Bosker, R. J. (1997). The Foundations of Educational Effectiveness. Oxford, UK: Pergamon.

Stalikas, A., Triliva, S., \& Roussi, P. (2012). Psychometric Tools in Greece. Athens: Pedio Publications.

Tschannen-Moran, M. \& Hoy, A. (2001). Teacher Efficacy: Capturing an Elusive Construct. Teaching and Teacher Education, 17, 783-805. https://doi.org/10.1016/S0742-051X(01)00036-1

Tschannen-Moran, M., \& Hoy, A. W. (2007). The Differential Antecedents of Self-Efficacy Beliefs of Novice and Experienced Teachers. Teaching and Teacher Education, 23, 944-956. https://doi.org/10.1016/j.tate.2006.05.003

Tschannen-Moran, M., \& Woolfolk Hoy, W. K. (1998). Teacher Efficacy: Its Meaning and Measure. Review of Education Research, 6, 202-248. https://doi.org/10.3102/00346543068002202

Xochelis, P. (2002). Teacher Education Today: International Necessity Greek Developments and Experiences. 2nd International Conference "Education at the Dawn of the 21st Century Historical-Comparative Approaches”, Patras, 4-6 October 2002. 
Zee, M., \& Koomen, H. M. (2016). Teacher Self-Efficacy and Its Effects on Classroom Processes, Student Academic Adjustment, and Teacher Well-Being: A Synthesis of 40 Years of Research. Review of Educational Research, 86, 981-1015.

https://doi.org/10.3102/0034654315626801

\section{Scientific Research Publishing}

Submit or recommend next manuscript to SCIRP and we will provide best service for you:

Accepting pre-submission inquiries through Email, Facebook, LinkedIn, Twitter, etc. A wide selection of journals (inclusive of 9 subjects, more than 200 journals) Providing 24-hour high-quality service User-friendly online submission system Fair and swift peer-review system Efficient typesetting and proofreading procedure Display of the result of downloads and visits, as well as the number of cited articles Maximum dissemination of your research work

Submit your manuscript at: http://papersubmission.scirp.org/ Or contact psych@scirp.org 